\title{
Erratum to: Novel Species of Centrohelid Heliozoans (Centroplasthelida) for Freshwaters of Central and Southern Vietnam
}

D. G. Zagumyonnyi ${ }^{a}$ * , E. S. Gusev ${ }^{b}$, A. A. Mylnikov ${ }^{a}$, and A. P. Mylnikov ${ }^{a}$

a Papanin Institute for Biology of Inland Waters, Russian Academy of Sciences, Borok, Nekouzskii raion, Yaroslavl oblast, Russia

${ }^{b}$ Institute of Plant Physiology Russian Academy of Sciences, Moscow, Russia *e-mail: zdmitryg@gmail.com

Submitted February 15, 2021; accepted for publication February 15, 2021

DOI: $10.1134 / \mathrm{S} 1995082921330014$

Page 359, Section RESULTS, the taxon "SAR Burki et al., 2008, emend. Adl et al., 2012" was inserted by mistake.

The original article can be found online at https://doi.org/10.1134/S1995082920030165 